\title{
PERANCANGAN SISTEM INFORMASI ADMINISTRASI DI PUSAT KEBUGARAN BERBASIS WEB
}

\author{
Bundjali Randy Robot, Alicia Amelia Elisabeth Sinsuw, Oktavian Lantang, Virginia Tulenan, \\ Program Studi Teknik Informatika, Fakultas Teknik, Universitas Sam Ratulangi \\ Jl. Kampus UNSRAT Bahu, Manado, 95115 \\ Telp : (0431) 852959, Fax : (0431) 823705 \\ Email : robotrandy@ymail.com
}

\begin{abstract}
Abstrak
Perkembangan teknologi komputer sekarang ini dengan kecepatan prosesnya telah memungkinkan pengembangan sistem informasi berbasis komputer. Penelitian ini membahas tentang pembuatan WEB disalah satu pusat kebugaran, karena melihat kualitas pengolahan data yang masih manual yaitu masih menggunakan kertas dan pulpen. Dengan menggunakan metodologi AUP, perancangan sistem informasi administrasi dipusat kebugaran berbasis web ini dapat meningkatkan kualitas proses administrasi dipusat kebugaran tersebut. Dengan menggunakan PHP dan MySQL pemilik pusat kebugaran bisa menjalankan usahanya tersebut. Dengan adanya sistem informasi ini, membantu kebutuhan pemilik pusat kebugaran dan membuat kinerja pemilik pusat kebugaran lebih maksimal dalam proses pengolahan berkas berupa pendataan anggota dari mana saja sekaligus menjaga data tetap aman.
\end{abstract}

Kata kunci : Administrasi, AUP, Basis data, MySQL, PHP, Sistem Informasi, Web

\section{PENDAHULUAN}

Perkembangan teknologi komputer sekarang ini dengan kecepatan prosesnya telah memungkinkan pengembangan sistem informasi berbasis komputer. Seiring dengan perkembangan tersebut dalam dunia olahraga harus juga mampu menjalankan teknologi yang ada,

Sekarang bisa dilihat guna menciptakan kualitas mayarakat yang lebih sehat, maka tempat pusat kebugaran berupa tempat GYM bisa menjadi tempat yang paling tepat bagi masyarakat untuk berolahraga. Dengan memanfaatkan teknologi komputer, kita bisa mendapatkan kemudahan untuk menyimpan, mengorganisasi dan melakukan pengambilan keputusan terhadap berbagai data. Didukung dengan perangkat lunak dan konfigurasi perangkat keras yang tepat, suatu tempat GYM dapat membangun suatu sistem informasi manajemen yang handal dan berpengaruh secara signifikan terhadap kinerja tempat GYM tersebut secara keseluruhan.

Berdasarkan latar belakang yang telah dijelaskan sebelumnya, diperoleh beberapa masalah yang hendak dikaji dalam tugas akhir ini yaitu belum memiliki sistem informasi di Hardcore GYM yang dalam hal ini masih melakukan akses data dengan cara manual sebagai media perekam data yang ada, pada proses akses data ini pemilik pusat kebugaran diharuskan untuk memasukkan data di buku secara manual terhadap para pelanggan yang ada di
Hardcore GYM. Melihat dari masalah yang ada maka rumusan yaitu dengan penelitian PERANCANGAN SISTEM INFORMASI ADMINISTRASI DI PUSAT KEBUGARAN BERBASIS WEB.

\section{LANDASAN TEORI}

\section{Sistem Informasi}

Menurut kertahadi (1995) dalam buku Hanif Al Fatta, Analisis \& Perancangan Sistem Informasi, 2007 mendefenisikan sistem informasi sebagai suatu alat untuk menyajikan sistem informasi dengan cara sedemikian rupa sehingga bermanfaat bagi penerimanya. Tujuannya adalah untuk menyajikan informasi guna pengambilan keputusan pada perencanaan, pemrakarsaan, pengorganisasian.

Peran sistem informasi terhadap kemajuan organisasi sudah tidak diragukan lain. Dengan dukungan sistem informasi yang baik maka sebuah perusahaan akan memiliki berbagai keunggulan kompetitif sehingga mampu bersaing dengan perusahaan lain. Persaingan bisnis dalam era informasi telah mencapai tahapan kompetisi yang sangat ketat, dimana sistem pengelolaan bisnis secara konvesional tidak lagi memadai. Oleh 
karena itu teknologi informasi berperan sebagai alat bantu untuk memudahkan pengelolaan suatu sumber daya yang dimiliki oleh suatu organisasi.

Sistem adalah suatu kesatuan usaha yang terdiri dari bagian - bagian yang berkaitan satu sama lain yang berusaha mencapai suatu tujuan dalam suatu lingkungan kompleks. Menurut Robert A. Laitch dan K. Roscoe Bavis sebagai berikut: “ sistem informasi dalam suatu organisasi yang mempertemukan kebutuhan pengolahan transaksi harian, mendukung operasi, bersifat manajerial dan kegiatan strategi dari suatu organisasi dan menyediakan pihak luar tertentu dengan laporan laporan yang diperlukan.

Stair (1992) dalam buku Hanif Al Fatta, Analisis dan Perancangan Sistem Informasi, 2007 menjelaskan bahwa dalam sebuah sistem informasi terdapat komponen - komponen seperti:

1. Perangkat Keras: Mencakup piranti - piranti fisik seperti computer, monitor, printer, dan lainnya.

2. Perangkat Lunak: Sekumpulan instruksi yang memungkinkan perangkat keras untuk dapat memproses data.

3. Prosedur: Sekumpulan aturan yang dipakai untuk mewujudkan pemrosesan data dan memunculkan keluaran yang dikehendaki.

4. Orang: Semua pihak yang bertanggung jawab dalam pengembangan sistem informasi, pemrosesan dan penggunaan keluaran sistem informasi.

5.Basis data: Sekumpulan table, hubungan, dan lain - lain yang berkaitan dengan penyimpanan data. 6.Jaringan Data dan Komunitas data: Sistem penghubung yang memungkinkan sumber (resources) dipakai secara bersama atau diakses sejumlah pemakai.

Pengolahan data menjadi informasi itu merupakan suatu siklus, yang terdiri dari tahap-tahap sebagai berikut:

1. Pengumpulan data. Pada tahap ini dilakukan suatu proses pengumpulan data yang asli dengan cara tertentu.

2. Input. Tahap ini merupakan proses pemasukan data dan prosedur pengolahan data ke dalam komputer melalui alat input seperti keyboard.

3. Pengolahan data. Tahap ini merupakan tahap di mana data diolah sesuai dengan prosedur yang telah dimasukkan. Kegiatan pengolahan data ini meliputi pengumpulan data, klasifikasi (pengelompokan), kalkulasi, pengurutan, penggabungan, peringkasan baik dalam bentuk tabel maupun grafik, penyimpanan dan pembacaan data dari tempat penyimpan data.

4. Output. Hasil pengolahan data akan ditampilkan pada alat output seperti monitor dan printer sebagai informasi.

5. Distribusi. Setelah proses pengolahan data dilakukasn, maka informasi yang dihasilkan harus segera didistribusikan. Proses ini tidak boleh terlambat dan harus diberikan kepada yang berkepentingan.

Ditinjau dari aplikasinya dan penggunaan dalam berbagai bidang, sistem

informasi dapat dibagi menjadi beberapa bagian yaitu (hanif al fattah, Analisis

\&Perancangan Sistem Informasi : 2007):

1. Routine Processing Sistem (RPS)

Routine Processing Sistem digunakan untuk melayani berbagai kebutuhan yang telah terdefinisi dan terjadwal secara rutin.

2. Decision Support Sistem (DSS).

Decision Support Sistem digunakan untuk melayani kebutuhan yang tidak dapat didefinisikan dengan baik dan biasanya terjadi pada saat perancangan.

3. Classical Management Information Sistem (CMIS)

Classical Management Information Sistem digunakan untuk melayani kebutuhan pembuatan laporan kegiatan yang telah terjadwal dan terdefinisi dengan baik.

4. Real Time Information Sistem (RTIS)

Real Time Information Sistem digunakan untuk melayani kegiatan yang mempunyai sifat harus direspon dengan cepat.

5. Ditributed Data Processing Sistem (DDPS)

Ditributed Data Processing Sistem digunakan untuk melayani kebutuhan yang telah tersebar secara geografis dengan sumber daya yang tersebar.

6. Transaction Processing Sistem (TPS)

Transaction Processing Sistem digunakan untuk melayani kegiatan yang bersifat transaksional yaitu membawa perubahan terhadap kondisi sistem yang ada.

\section{PHP}

PHP atau kependekan dari Hypertext Preprocessor adalah salah satu bahasa pemrograman open source yang sangat cocok atau dikhususkan untuk pengembangan web dan dapat ditanamkan pada sebuah skripsi HTML. Bahasa PHP dapat dikatakan menggambarkan beberapa bahasa pemrograman seperti C, Java, dan Perl serta mudah untuk dipelajari. Menurut Didik Dwi Prasetyo (2004), PHP merupakan bahasa scripting server - side, dimana pemrosesan datanya dilakukan pada sisi server. Sederhananya, serverlah yang akan menerjemahkan skrip program, baru kemudian hasilnya akan dikirim kepada client yang melakukan permintaan. Menurut Oktavian (2010:31), "PHP adalah akronim dari Hypertext Preprocessor, yaitu suatu bahasa pemrograman berbasiskan kode - kode (script) yang digunakan untuk mengolah suatu data dan mengirimkannya kembali ke web browser menjadi kode HTML". 
Menurut Kustiyaningsih (2011:114), "PHP (atau resminya PHP: Hypertext Preprocessor) adalah skrip bersifat server - side yang ditambahkan ke dalam HTML".

Sistem kerja dari PHP diawali dengan permintaan yang beasal dari halaman website oleh browser. Berdasarkan URL atau alamat website dalam jaringan internet, browser akan menemukan sebuah alamat dari webserver, mengidentifikasi halaman yang dikehendaki, dan menyampaikan segala informasi yang dibutuhkan oleh webserver. Selanjutnya webserver akan mencarikan berkas yang diminta dan menampilkan isinya di browser. Browser yang mendapatkan isinya segera menerjemahkan kode HTML dan menampilkannya. Lalu bagaimana apabila yang dipanggil oleh user adalah halaman yang mengandung script PHP ? Pada prinsipnya sama dengan memanggil kode HTML, namun pada saat permintaan dikirim ke web-server, web-server akan memeriksa tipe file yang diminta user. Jika tipe file yang diminta adalah PHP, maka akan memeriksa isi script dari halaman PHP tersebut. Apabila dalam file tersebut tidak mengandung script PHP, permintaan user akan langsung ditampilkan ke browser, namun jika dalam file tersebut mengandung script PHP, maka proses akan dilanjutkan ke modul PHP sebagai mesin yang menerjemahkan script-script PHP dan mengolah script tersebut, sehingga dapat dikonversikan ke kode-kode HTML lalu ditampilkan ke browser user.

\section{3. . MySQL dan Basis Data}

Menurut Kustiyahningsih (2011:145), "MySQL adalah sebuah basis data yang mengandung satu atau jumlah table. Table terdiri atas sejumlah baris dan setiap baris mengandung satu atau sejumlah table. Tabel terdiri atas sejumlah baris dan setiap baris mengandung satu atau sejumlah table". Menurut Wahana Komputer (2010:21), MySQL adalah database server open source yang cukup popular keberadaannya. Dengan berbagai keunggulan yang dimiliki, membuat software database ini banyak digunakan oleh praktisi untuk membangun suatu project. Adanya fasilitas API (Application Programming Interface yang dimiliki oleh MySQL, memungkinkan bermacam - macam aplikasi komputer yang ditulis dengan berbagai bahasa pemrograman dapat mengakses basis data MySQL. MySQL adalah sebuah perangkat lunak sistem manajemen basis data SQL (bahasa inggris: database management system) atau DBMS yang multithread, multiuser, dengan sekitar 6 juta instalasi di seluruh dunia. MySQL AB membuat MySQL tersedia sebagai perangkat lunak gratis dibawah lisensi GNU General Public License (GPL), tetapi mereka juga menjual dibawah lisensi komersial untuk kasus kasus dimana penggunaannya tidak cocok dengan penggunaan GPL.
MySQL adalah sebuah implementasi dari sistem manajemen basis data relasional (RDBMS) yang didistribusikan secara gratis dibawah lisensi GPL (General Public License). Setiap pengguna dapat secara bebas menggunakan MySQL, namun dengan batasan perangkat lunak tersebut tidak boleh dijadikan produk turunan yang bersifat komersial. MySQL sebenarnya merupakan turunan salah satu konsep utama dalam basis data yang telah ada sebelumnya, SQL (Structured Query Language). SQL adalah sebuah konsep pengoperasian basis data, terutama untuk pemilihan atau seleksi dan pemasukkan data, yang memungkinkan pengoperasian data dikerjakan dengan mudah secara otomatis.

Kehandalan suatu sistem basis data (DBMS) dapat diketahui dari cara kerja pengoptimasi-nya dalam melakukan perintah - perintah SQL yang dibuat oleh pengguna maupun program - program aplikasi yang memanfaatkannya. Sebagai database server, MySQL dapat dikatakan lebih unggul dibandingkan database server lainnya dalam query data. Hal ini terbukti untuk query yang dilakukan oleh single user, kecepatan query MySQL bisa sepuluh kali lebih cepat dari PostgreSQL dan lima kali lebih cepat dibandingkan Interbase.

Basis data adalah sebuah kumpulan informasi yang disimpan didalam computer secara sistematik sehingga dapat diperiksa menggunakan suatu program computer untuk memperoleh informasi dari basis data tersebut. Menurut Fabbri dan Schwab, basis data adalah sistem berkas terpadu yang dirancang terutama untuk meminimalkan pengulangan data.

Menurut George Tsu-Der Chou basis data merupakan kumpulan informasi bermanfaat yang diorganisasikan ke dalam aturan yang khusus. Sekarang peran basis data sangatlah menonjol. Pemrosesan basis data menjadi perangkat andalan yang kehadirannya sangat diperlukan oleh berbagai institusu dan perusahaan. Basis data tidak hanya mempercepat pemrolehan informasi, tetapi juga dapat meningkatkan pelayanan kepada pelanggan. Bagi perusahaan, keuntungan seperti ini dapat meningkatkan daya saingnya terhadap perusahaan lain. Hal ini pulahlah yang mendorong banyak perusahaan yang menggunakan pemrosesan manual mulai beralih memanfaatkan basis data.

Menurut sejarah, sistem pemrosesan basis data terbentuk setelah masa sistem pemrosesan manual dan sistem pemrosesan berkas. Perkembangan teknologi basis data tidak lepas dari perkembangan perangkat keras dan perangkat lunak. Perkembangan teknologi jaringan komputer dan komunikasi data merupakan salah satu penyumbang kemajuan penerapan basis data, yang kemudian melahirkan sistem basis data terdistribusi. 


\section{METODOLOGI PENELITIAN}

\subsection{Metode Perancangan Sistem}

\subsubsection{Metodologi AUP (Agile - Unified Process)}

Metodologi AUP atau Agile - Unified Process merupakan suatu metodologi pengembangan perangkat lunak yang mulai marak digunakan. Metodologi ini paling cocok digunakan oleh mahasiswa dalam menyelesaikan tugas proyek mata kuliah ataupun mengerjakan laporan Kerja Praktek dan Tugas Akhir.

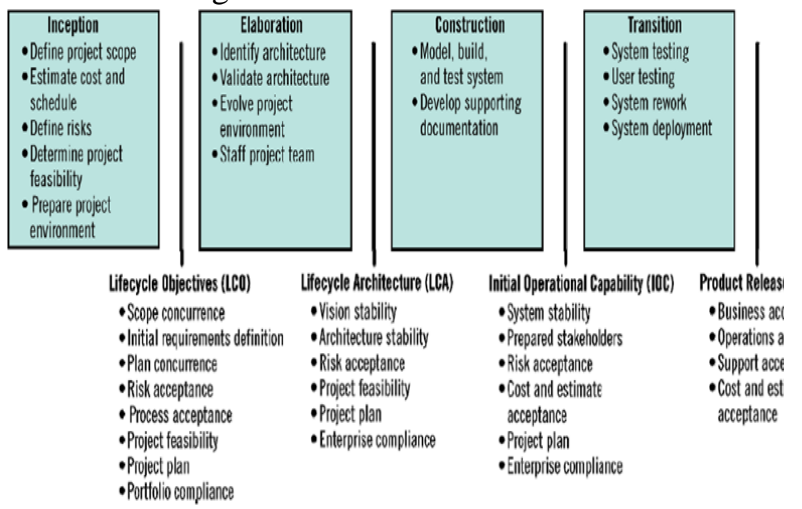

Gambar 1. Menunjukkan Tahapan Proses dan Aktivitas Metodologi AUP

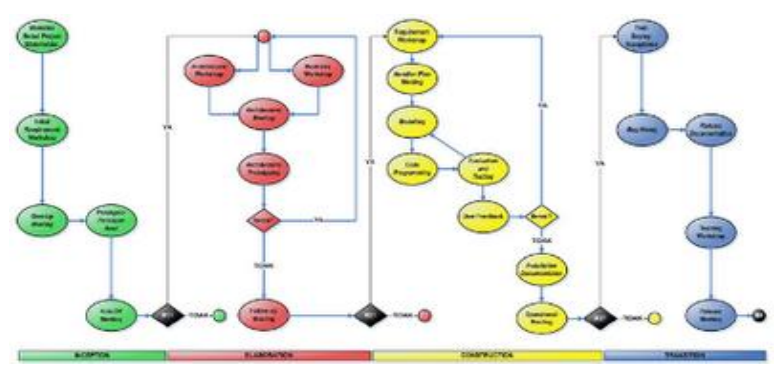

Gambar 2. Menunjukkan urutan akvitas pada masing-masing fase AUP

\section{TAHAP ELABORATION}

\subsection{Proses Berjalan (AS-IS SISTEM)}

Dari permasalahan yang terjadi, yaitu bahwa Hardcore GYM masih secara manual dalam proses menyimpan data dengan masih menggunakan kertas dan pulpen dalam mengolah data sehingga kinerjanya belum maksimal. Aplikasi ini di rancang untuk mempermudah pemilik gym untuk mengelola pusat kebugarannya dengan menggunakan akses internet. Penjelasan mekanisme kerja aplikasi ini dapat di lihat pada gambar 4. di bawah ini.

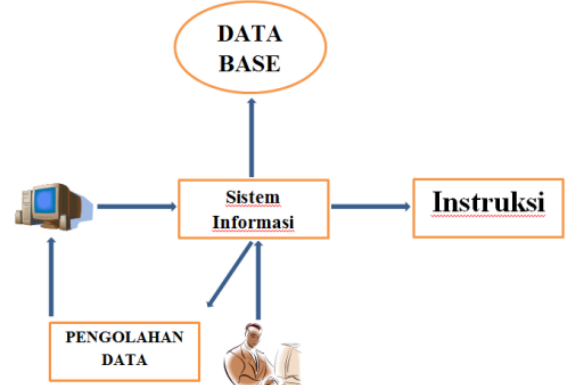

Gambar 3. Mekanisme kerja aplikasi

\section{Analisa Kebutuhan Sistem (TO BE SISTEM)}

Agar kegiatan pengelolaan pusat kebugaran berjalan dengan efektif dan efisien maka dibutuhkan suatu sistem informasi yang handal, mudah dan efisien. Sistem informasi yang akan diterapkan nantinya ialah berbasis Web. Dengan sistem ini maka dapat memberikan kemudahan bagi pemilik pusat kebugaran

dalam menginput data pelanggan. Memudahkan pemilik pusat kebugaran dalam mengakses data yang diperlukan dan dapat dilakukan secara online.

\section{Permasalahan Yang Dihadapi}

Belum dimilikinya sistem informasi untuk pusat kebugaran di Hardcore GYM Manado. Dalam hal ini masih melakukan akses data dengan menggunakan kertas dan pulpen sebagai media perekam data yang ada. Dengan melihat jumlah peminat pusat kebugaran yang ada di Manado, maka permasalahan yang di hadapi Hardcore GYM semakin berat dalam proses mengolah administrasi khususnya pendataan anggota dan menjaga konsistensi anggota.

\section{Usulan Penyelesaian Masalah}

Sistem didesain agar dapat mendukung kesuluruhan proses yang ada di pusat kebugaran yang pada akhirnya meningkatkan efektivitas dan efisiensi. Aplikasi ini dibuat dengan interface yang mudah digunakan oleh pemilik pusat kebugaran. Bagi pemilik pusat kebugaran akan memperkecil resiko terjadinya kehilangan data yang masih digunakan secara manual untuk pengolahan datanya.

\section{Functional Model}

Tahap ini menjelaskan tentang use case diagram dan use case description.

\subsection{Use Case Diagram}

Menggambarkan hubungan antara aktor dan sistem. Adapun aktor dalam sistem informasi administrasi di pusat kebugaran berbasis we sebagai berikut. 


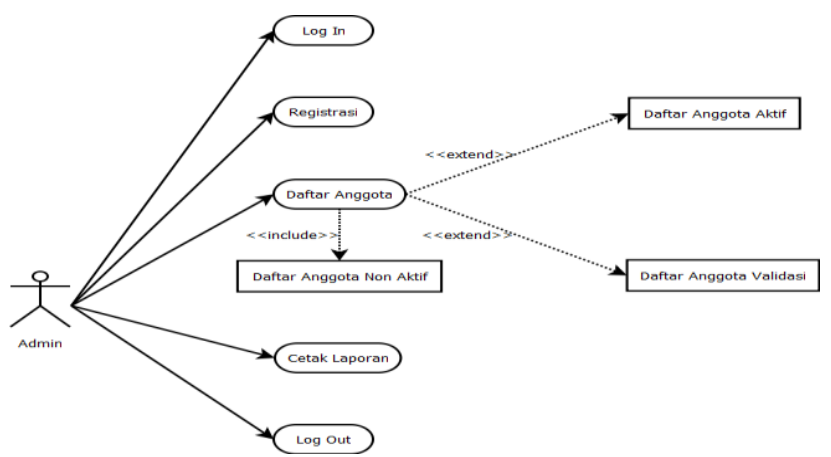

Gambar 4. Use Case Diagram

\section{Pemodelan Struktural}

Bagian ini Berisikan CRC Cards, Class Diagram dan Object Diagram.

\subsection{Class Diagram}

Class diagram merupakan pemodelan statis dari kelas-kelas dan hubungan antara kelaskelas yang ada.

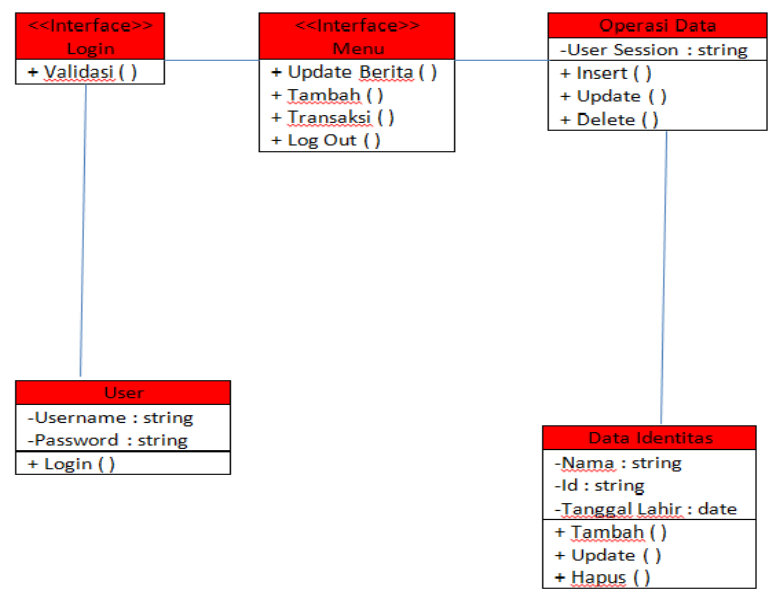

Gambar 5. Class Diagram

\subsection{Behavioral Models}

Tahap ini memberikan gambaran perilaku dari objek yang ada pada aplikasi. Dalam tahap ini dihasilkan sequence diagram dan activity diagram.

\section{Sequence Diagram}

Sequence diagram merupakan pemodelan dinamis yang mengilustrasikan hubungan antara objek di dalam use case dan message yang dikirim ADMIN

里

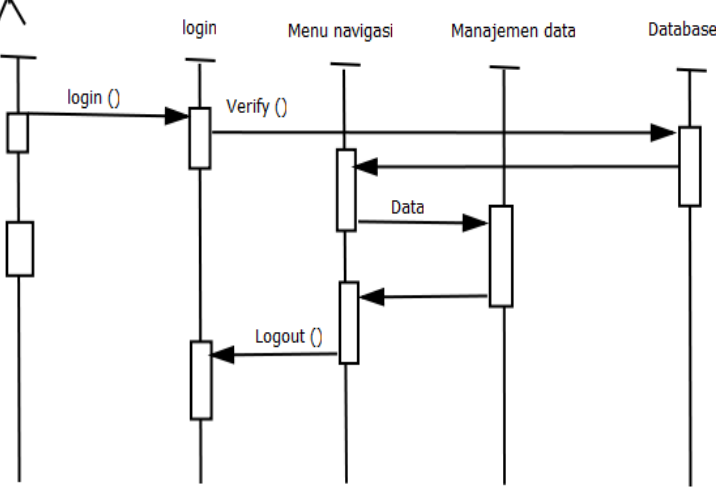

Gambar 7. Sequence Diagram

\section{TAHAP CONTRUCTION}

3.1 Design Method and Class

Design Method and Class menjelaskan seluruh kegiatan yang dilakukan selama fase design. Pada tahapan ini dihasilkan revisi dari use case diagram, sequence diagram, dan activity diagram.

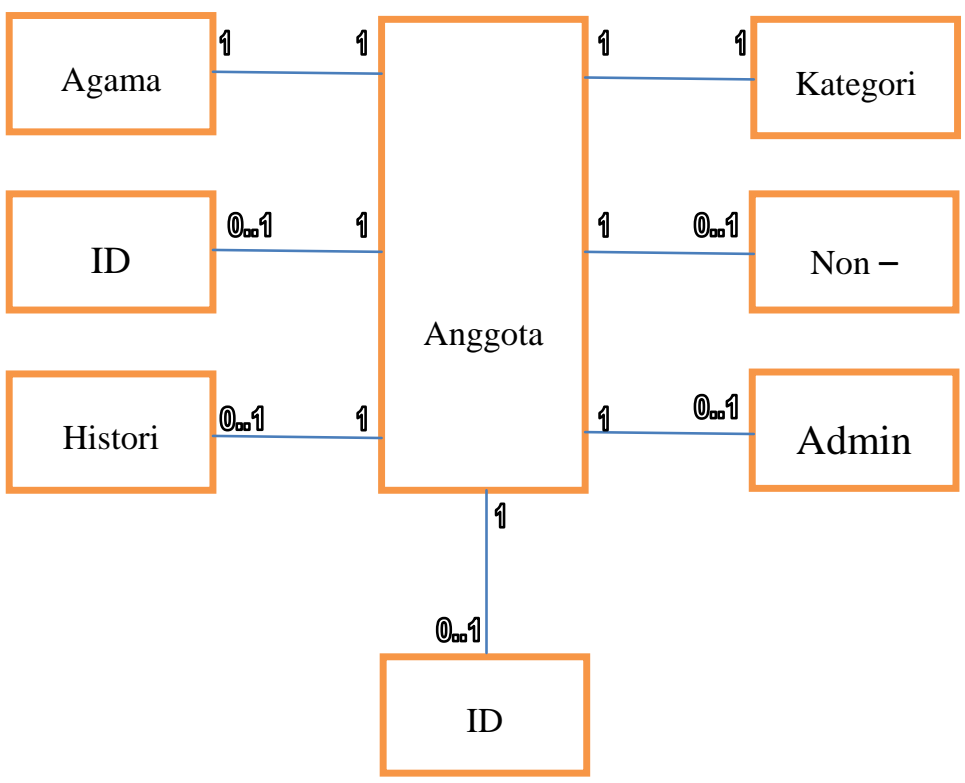

Gambar 6. ERD Design 
4. PEMBAHASAN

4.1. User Interface Design

\subsubsection{Log In}

Hardcore
fitmess centre
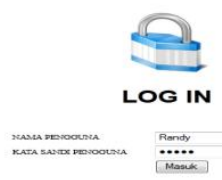

Gambar 4.1 Log In

Admin memasukkan user name dan password untuk mengolah data.

\subsubsection{Beranda}

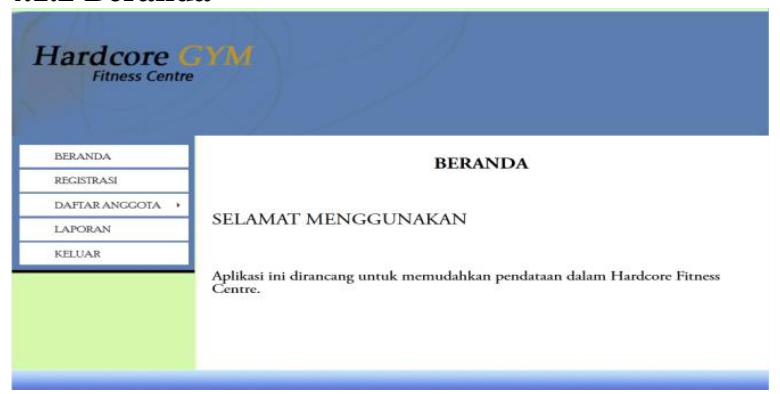

Gambar 4.2 Beranda

Tampilan awal berfungsi untuk memasukkan data.

\subsubsection{Registrasi Anggota}

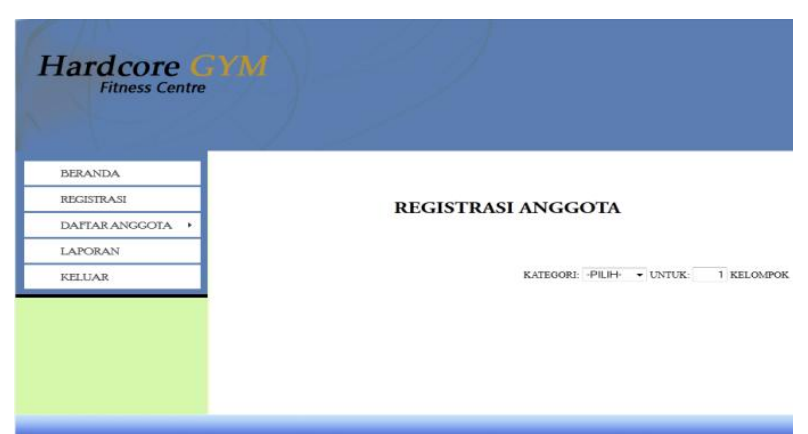

Gambar 4.3 Registrasi Anggota

Halaman untuk admin menginput data anggota baru.

\subsubsection{Daftar Anggota Yang Aktif}

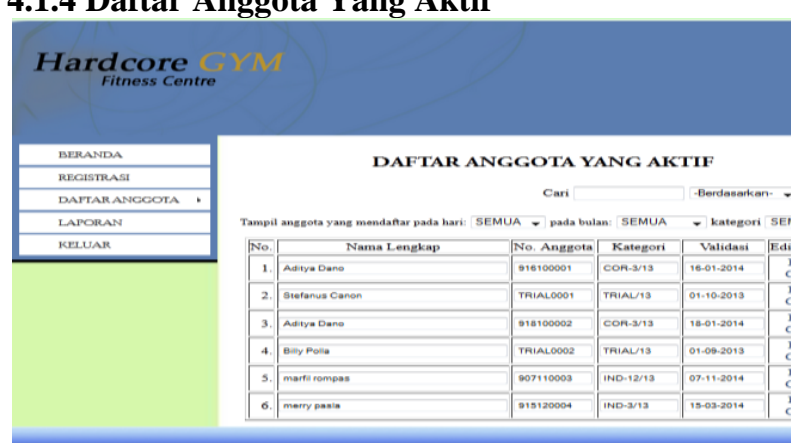

Gambar 4.4 Daftar Anggota yang Aktif
Tampilan menunjukkan data anggota yang aktif.

\subsubsection{Daftar Anggota Validasi}

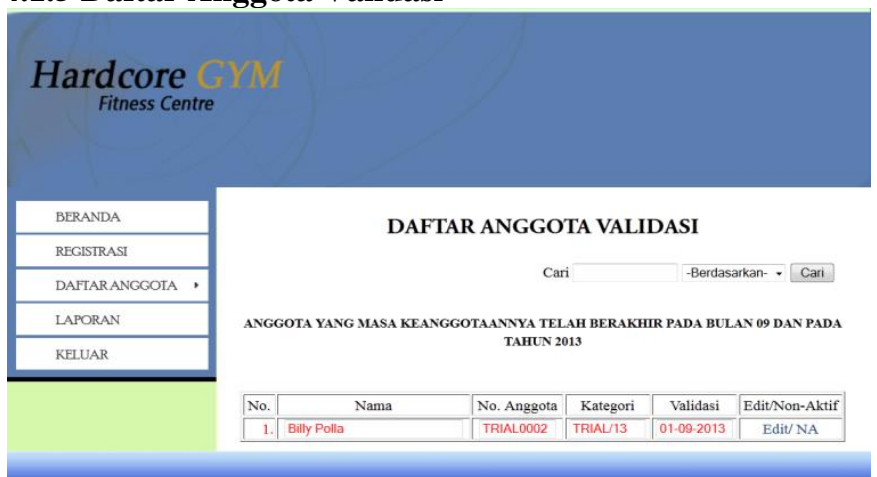

Gambar 4.5 Daftar Anggota Validasi

Tampilan yang menunjukkan data anggota yang sudah habis masa keanggotaannya.

\subsubsection{Daftar Anggota Non-Aktif}

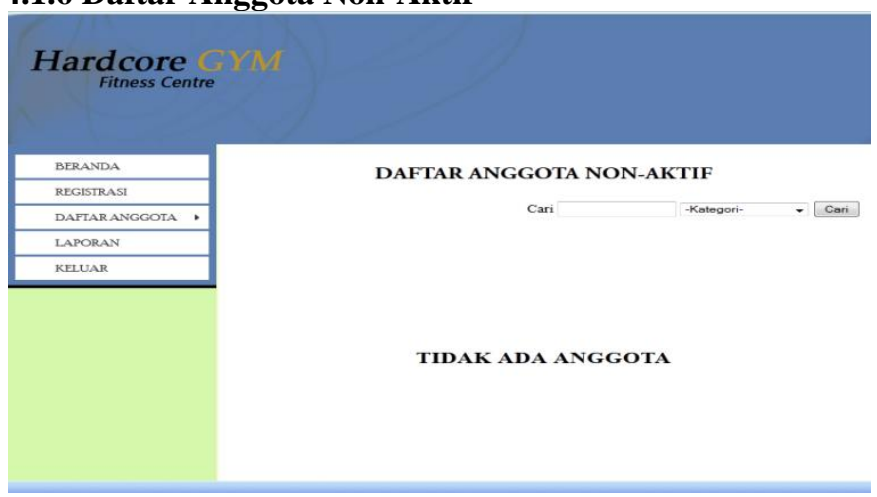

Gambar 4.6 Daftar Anggota Non-Aktif

Tampilan yang menunjukkan data anggota yang sudah tidak aktif.

\subsubsection{Laporan}

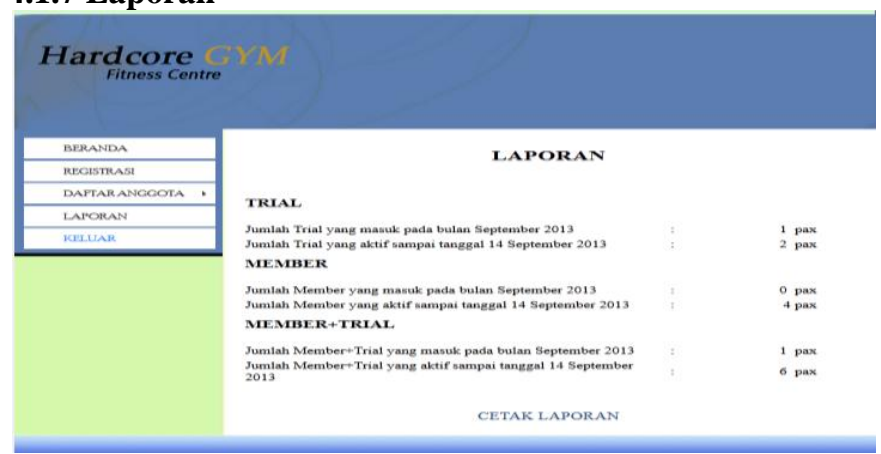

Gambar 4.7 Laporan

Berfungsi untuk melihat dan mencetak laporan data.

\subsection{Design Physical Layer Architecture}

Sistem Informasi Administrasi di Pusat Kebugaran berbasis web ini dirancang dengan beberapa langkah berdasarkan dengan metodologi yang digunakan secara sistematis dan berurutan. 


\subsection{Deployment Diagram}

Diagram ini menunjukkan hubungan antara komponen hardware dan infrastruktur jaringan dalam penggunaan aplikasi.

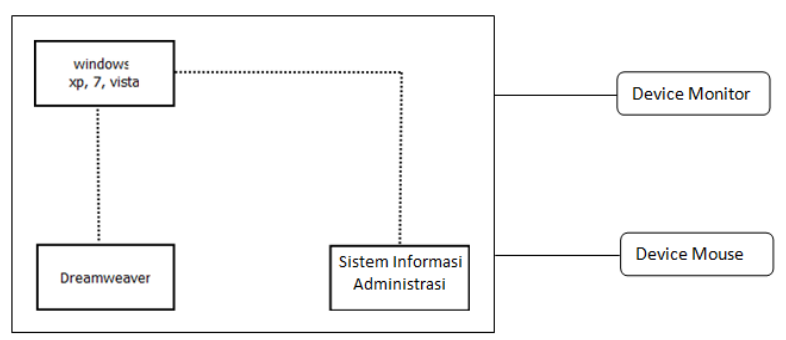

Gambar 4.8 Diagram komponen dan infrasturktur jaringan

\section{PENUTUP}

\section{Kesimpulan}

Hal-hal yang dapat disimpulkan adalah sebagai berikut:

1. Berdasarkan proses analisis yang dilakukan maka dapat disimpulkan aplikasi ini dapat membantu kebutuhan pemilik pusat kebugaran yang ada di Hardcore gym.

2. Dengan adanya aplikasi sistem informasi berbasis web menggunakan PHP dan MySQL ini membuat kinerja dari pemilik pusat kebugaran lebih maksimal dalam proses pengolahan berkas.

3. Dengan aplikasi ini membantu pemilik pusat kebugaran khususnya Hardcore gym untuk mengontrol dan mengolah administrasi khususnya pendataan anggota, dari mana saja sekaligus menjaga data tetap aman.

4. Dengan menggunakan metode AUP (Agile Unified Process), metode ini sangat membantu dalam proses pembuatan aplikasi sistem informasi administrasi di pusat kebugaran berbasis web.

\subsection{Saran}

Beberapa saran berkaitan dengan pengembangan sistem ini di masa yang mendatang adalah sebagai berikut:

1. Diperlukannya komputer yang cukup baik didalam menjalankan dan mengimplementasikan sistem ini.

2. Diperlukannya orang yang bisa mengerti atau menjalankan sistem ini, khususnya pemilik pusat kebugaran

\section{DAFTAR PUSTAKA}

1. A.M. Hirin \&Virgi. 2011. PHP \& $M y S Q L$, Jakarta: Prestasi Pustaka.
2. Budi Sutedjo Dharma Oetomo. 2006. Perancangan \& Pembangunan Sistem Informasi, Yogyakarta: ANDI

3. Janner Simarmata \& Iman Paryudi. 2005. Basis Data, Yogyakarta: ANDI.

4. Roger S. Pressman, Ph.D. 2010. Rekayasa Perangkat Lunak, Yogyakarta: ANDI

5. Stanley Karouw. 2012. http://stanlysk.blogspot.com/2012/04/meto dologi-aup.html. Diakses 25 September $\underline{2012}$

6. Yakub. 2012. Pengantar Sistem Informasi, Yogyakarta: Graha Ilmu. 